\title{
Induction of Drug-Metabolizing Enzymes by Fractionated Commercial Polybrominated Biphenyls (PBBs)
}

\author{
L. ROBERTSON \\ School of Public Health, The University of Michigan, Ann Arbor, Michigan 48109
}

AND

A. Parkinson and S. Safe

The Guelph-Wuterloo Centre for Graduate Work in Chemistry, Guelph Campus, Department of Chemistry. University of Guelph, Guelph, Ontario NlG 2WI Canada

Received April 28, 1980; accepted August 11. 1980

\begin{abstract}
Induction of Drug-Metabolizing Enzymes by Fractionated Commercial Polybrominated Biphenyls (PBBs). Robertson, L., Parkinson, A., and Safe, S. (1981). Toxicol. Appl. Pharmacol. 57, 254-262. A commercial polybrominated biphenyl mixture was separated chromatographically into two fractions on neutral alumina $\left(A_{A}\right.$ and $A_{B}$ ) and into three fractions on Florisil $\left(F_{A}, F_{B}\right.$, and $\left.F_{C}\right)$ by sequential elution with solvents of increasing polarity. Using established methods, the activity of each fraction as hepatic microsomal cytochrome $P$-450- and/or cytochrome $P$-448-dependent monooxygenase enzyme inducers was examined in the male Wistar rat. Like the coadministration of phenobarbitone and 3-methylcholanthrene, commercial PBBs, either unfractionated or reconstituted from its various fractions, induced both cytochromes $P-450$ and $P-448$. Both cytochromes were also induced by the less-polar fractions $A_{A}$ and $F_{A}$. In contrast. little or no inductive effects were exhibited by the more polar Florisil fractions, $F_{B}$ and $F_{C}$, indicating that the ability of commercial PBBs to induce cytochrome $\boldsymbol{P}-448$ is not due to contaminating brominated dibenzofurans or dibenzodioxins. Unlike the polar Florisil fraction, the more polar alumina fraction, $A_{B}$, was a potent microsomal enzyme inducer. This fraction was enriched in $2,3.3^{\prime}$,4,4',5-hexa- and 2,2',3,3',4,4',5-heptabromobiphenyl and also contained unassigned monochloro derivatives of a penta- and hexabromobiphenyl, namely $\mathrm{C}_{12} \mathrm{H}_{4} \mathrm{Br}_{5} \mathrm{Cl}$ and $\mathrm{C}_{12} \mathrm{H}_{3}$ $\mathrm{Br}_{6} \mathrm{Cl}$, respectively. The data strongly suggest that the biologic effects of the commercial polybrominated biphenyl mixture are due to the various halogenated biphenyls present. These results are discussed in terms of the reported toxic potency of each PBB fraction and with reference to the known biologic activity of individual polybrominated biphenyl congeners or their chloro analogs.
\end{abstract}

The commercial polybrominated biphenyl (PBB) mixture, fireMaster BP-6, has been fractionated by column chromatography using Florisil (Hass et al. , 1978) and alumina (Kimbrough et al., 1977) and the various fractions evaluated toxicologically. These fractionation experiments were inspired by similar studies with commercial polychlori- nated biphenyl (PCB) mixtures which revealed the presence of highly toxic chlorinated dibenzofurans in American (Bowes $e t$ al. , 1975), European (Vos et al., 1970), and Japanese PCBs (Roach and Pomerantz, 1974). However, brominated dibenzofurans have not been detected in the commercial PBB mixtures, fireMaster BP-6 or fire- 
Master FF-1 (Hass et al., 1978). Despite the absence of brominated dibenzofurans from fireMaster BP-6, the more polar fraction of this PBB mixture eluted from an alumina column is a potent inducer of rabbit ear hyperkeratosis (Kimbrough et al., 1977). The toxic fireMaster components present in the more polar alumina fraction but absent from the more polar Florisil fraction have not been identified.

This study was designed to characterize further the biologic effects of fireMaster BP-6 and its various Florisil and alumina fractions. Each fraction was tested as an inducer of hepatic microsomal cytochrome $P$ 450-dependent monooxygenase activity (dimethylaminoantipyrine $N$-demethylase) and/or cytochrome $\boldsymbol{P}$-448-dependent monooxygenase activity (benzo[ $a]$ pyrene hydroxylase) in the male Wistar rat. An attempt was made to correlate the qualitative and quantitative effects of each fireMaster BP-6 fraction with its chemical composition. This approach has the distinct advantage over the toxicity studies in that many of the individual components of fireMaster BP- 6 have been evaluated as inducers of the microsomal drug-metabolizing enzymes (summarized in Table 2) and structure-activity rules have been reported for the structurally related PCBs (Poland and Glover, 1977; Goldstein, 1979; Parkinson et al., 1980a).

For several classes of halogenated aryl hydrocarbons, including PCBs, there is an excellent correlation between toxicity and the ability of individual congeners to induce the cytochrome $P$-448-dependent monooxygenase, benzo[a]pyrene hydroxylase (Poland and Glover, 1977; Yoshimura et al. , 1979; Poland et al., 1979). For the PCBs this correlation is supported by the fact that 3,3',4,4'-tetra- (Goldstein et al., 1977), 3,3',4,4',5-penta- (Yoshimura et al., 1979;

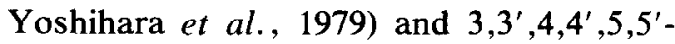
hexachlorobiphenyl (Goldstein et al., 1977; Poland and Glover, 1977), which induce cytochrome $P-448$, and $2,3,3^{\prime}, 4,4^{\prime}$-penta-
(Yoshimura et al., 1979; Parkinson et al., 1980b), 2,3',4,4',5-penta-(Parkinson et al., 1980b), and $2,3,3^{\prime}, 4,4^{\prime}, 5$-hexachlorobiphenyl (Yoshihara et al., 1979; Parkinson et al., 1980b) which induce both cytochrome $P-448$ and $P-450$, appear to be more toxic than other isomers which have been examined (Yoshimura et al., 1979; Yoshihara et al., 1979; McKinney et al., 1976; Yamamoto et al., 1976; Ax and Hansen, 1975). Polybrominated biphenyls may also be a class of halogenated aryl hydrocarbons for which toxicity correlates with cytochrome $P-448$ induction. Therefore, we have addressed the possibility that the pattern of drug-metabolizing enzymes induced by the various fireMaster BP-6 fractions can be correlated with both their toxic potency and with the known inductive effects of the individual components present in each fraction.

\section{METHODS}

Materials. FireMaster BP-6 (Lot 7062) was a gift of Michigan Chemical Corporation, St. Louis, Michigan. Florisil (60-100 mesh) and certified neutral alumina (80-200 mesh, Brockman activity 1) were purchased from Fischer Scientific Company. All biochemicals were obtained as previously described (Parkinson and Safe, 1979).

Fractionation of fireMaster on Florisil. Three fractions from fireMaster $\left(F_{A}, F_{B}\right.$, and $\left.F_{C}\right)$ were prepared by Florisil column chromatography according to the method of Vos et al. (1970). Approximately $8 \mathrm{~g}$ of fireMaster dissolved in $900 \mathrm{ml}$ petroleum ether (BP $\left.37.9-56.1^{\circ} \mathrm{C}\right)$ was applied to a heat-activated Florisil column ( $4.5 \mathrm{~cm}$ (i.d.) $\times 7.0 \mathrm{~cm})$ and eluted sequentially with: (a) an additional $900 \mathrm{ml}$ petroleum ether to give fraction $\mathrm{A}\left(\mathrm{F}_{\mathrm{A}}\right)$; (b) $1000 \mathrm{ml}$ petroleum ether:diethyl ether $(95: 5, v / v)$ to give fraction $B\left(F_{B}\right)$; and $(c) 500$ $\mathrm{ml}$ acetone to give fraction $\mathrm{C}\left(\mathrm{F}_{\mathrm{C}}\right)$. The percentage by weight of fireMaster present in $F_{A}, F_{B}$, and $F_{C}$ was $99,0.6$, and $0.4 \%$, respectively.

Fractionation of fireMaster on alumina. Two fractions from fireMaster $\left(A_{A}\right.$ and $\left.A_{B}\right)$ were prepared by alumina column chromatography according to the method of Porter and Burke (1971). Approximately $6 \mathrm{~g}$ of fireMaster dissolved in $250 \mathrm{ml}$ hexanes: dichloromethane $(99: 1, \mathrm{v} / \mathrm{v})$ was applied to a neutral alumina column $(4.5 \mathrm{~cm}$ (i.d.) $\times 5.0 \mathrm{~cm})$ and eluted sequentially with: (a) an additional $1250 \mathrm{ml}$ hexanes: 


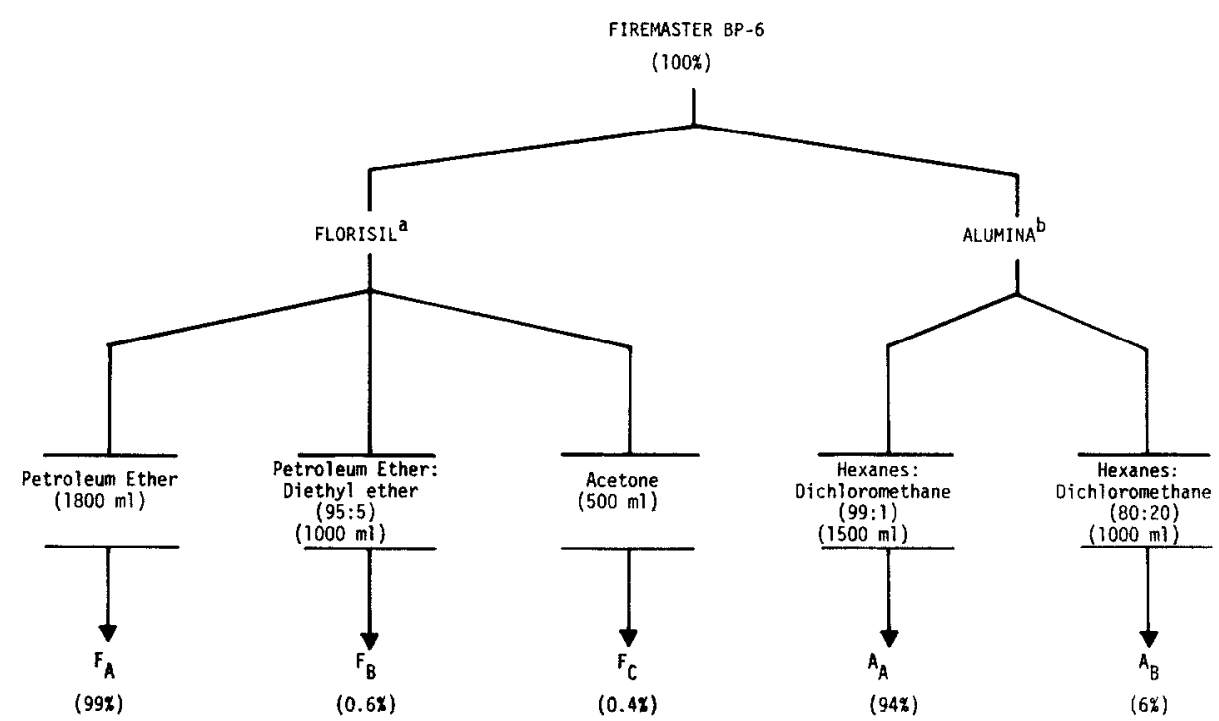

FIG. 1. The fractionation of fireMaster BP-6 on Florisil and alumina by sequential elution with solvents of increasing polarity. (a) $100 \%$ fireMaster $=8 \mathrm{~g}$ : order of polarity $=F_{C}>F_{B}>F_{A} ;$ (b) $100 \%$ fireMaster $=6 \mathrm{~g}$; order of polarity $=\mathrm{A}_{\mathrm{B}}>\mathrm{A}_{\mathrm{A}}$.

dichloromethane to give fraction $\mathrm{A}\left(\mathrm{A}_{\mathrm{A}}\right)$; and (b) 1000 $\mathrm{ml}$ hexanes:dichloromethane $(80: 20, \mathrm{v} / \mathrm{v})$ to give fraction $B\left(A_{B}\right)$. The percentage by weight of fireMaster present in $A_{A}$ and $A_{B}$ was 94 and $6 \%$, respectively.

These fractionation procedures are schematically represented in Fig. 1.

Gas chromatographic (gc) analysis of fireMaster fractions. The two alumina fractions, $A_{A}$ and $A_{B}$, and three Florisil fractions, $F_{A}, F_{B}$, and $F_{C}$, were analyzed by gas chromatography (GC) using a Hewlett-Packard model $5710 \mathrm{~A}$ chromatograph equipped with a glass column $(4 \mathrm{~mm}$ (i.d.) $\times 1.2 \mathrm{~mm})$ packed with $1.5 \%$ OV17 and $2 \%$ OV210 on gas chrom Q (100-200 mesh) (Chromatographic Specialties). The column was operated isothermally at $260^{\circ} \mathrm{C}$ with both the injector and detector at $300^{\circ} \mathrm{C}$. Each component was quantified by flame ionization detector (FIC) response using a Hewlett-Packard integrator-recorder.

Fractionation of the more polar alumina fraction. $A_{B}$. Due to its potent biologic activity (cf. Results), the more polar alumina fraction, $A_{B}$, was fractionated by thin layer chromatography (TLC). A $100 \times 20-\mathrm{cm}$ plate, coated with heat-activated silica gel $\mathbf{H F}_{254}$ (BDH Chemicals), was developed in petroleum ether (BP $37.9-56,1^{\circ} \mathrm{C}$ ). The compounds present in each of five equal bands were analyzed by gas chromatography-mass spectrometry (GC-MS) using a VG Micromass 7070F double-focusing mass spectrometer interfaced with a Perkin Elmer Sigma 3 GC and a VG Data System 2000. The glass chromatographic column (4 mm (i.d.) $\times 0.6 \mathrm{~m}$ ) was packed with $3 \% \mathrm{OV} 1$ on Chromosorb W, HP and operated isothermally at $260^{\circ} \mathrm{C}$. The column fed a glass jet separator. The mass spectrometer was operated with $70 \mathrm{eV}$ nominal ionizing energy and a $100 \mu \mathrm{A}$ electron current. The ion source temperature was $200^{\circ} \mathrm{C}$.

Each of the five TLC fractions of $A_{B}$ was scanned for tetra-, penta-, hexa-, and heptabromodibenzofurans (at $m / e 484,562,642$, and 720 , respectively) and for

\section{TABLE}

The Dosage Regimen for fireMaster and Its Florisil and Alumina Fractions

\begin{tabular}{lcc}
\hline \multicolumn{1}{c}{ Treatment } & $\begin{array}{c}\text { Percentage } \\
\text { weight of } \\
\text { fireMaster }\end{array}$ & $\begin{array}{c}\text { Dose } \\
\left(\mathrm{mg} \mathrm{kg}^{-1}\right. \\
\left.\text { injection }^{-1}\right)^{a}\end{array}$ \\
\hline fireMaster BP-6 & 100 & 100 \\
Florisil fractions & & \\
$\mathrm{F}_{\mathrm{A}}$ & 99 & 100 \\
$\mathrm{~F}_{\mathrm{B}}$ & 0.6 & 0.60 \\
$\mathrm{~F}_{\mathrm{C}}$ & 0.4 & 0.40 \\
$\mathrm{~F}_{\mathrm{ABC}}$ & 100 & 101 \\
Alumina fractions & & \\
$\mathrm{A}_{\mathrm{A}}$ & 94 & 100 \\
$\mathrm{~A}_{\mathrm{B}}$ & 6 & 6.7 \\
$\mathrm{~A}_{\mathrm{AB}}$ & 100 & 107 \\
\hline
\end{tabular}

a Rats were injected on Days 1 and 3 and killed by cervical dislocation on Day 6. 
the corresponding bromodibenzodioxins (at $m / e 500$, 578,658 , and 736 , respectively).

Animal treatment, isolation of microsomes and assays. One-month-old Wistar rats, average weight 100 $\mathrm{g}$, were housed in wire cages and allowed free access to Purina Certified Rodent Chow (5002) and water. FireMaster BP-6 or its various fractions were dissolved in corn oil and injected ip on Days 1 and 3 at doses shown in Table 1 . The animals were killed on Day 6 by cervical dislocation.

It should be noted that each fireMaster fraction was administered on the basis of its relative weight in the original fireMaster BP-6 sample. In addition, the original fireMaster BP-6 was reconstituted by recombining the three Florisil fractions (designated $F_{A B C}$ ) and the two alumina fractions (designated $A_{A B}$ ).

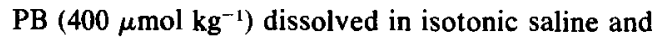
MC $\left(100 \mu \mathrm{mol} \mathrm{kg}^{-1}\right)$ dissolved in corn oil were administered individually as well as coadministered to animals on Days 1 and 2 and the animals were killed on Day 3. Controls received a corresponding volume of corn oil $\left(5 \mathrm{ml} \mathrm{kg} \mathrm{kg}^{-1}\right)$. All animals were fasted over the last $24 \mathrm{hr}$ to lower liver glycogen levels.

The rat livers were perfused via the hepatic portal vein with ice-cold isotonic saline supplemented with EDTA (0.1 mM). The balanced livers were transferred to preweighed, ice-cold solutions of sucroseEDTA (0.25 $\mathrm{M}-0.1 \mathrm{mM})$ and the liver weights determined. The microsomal fraction was harvested as a $100,000 \mathrm{~g}$ pellet by further centrifugation of a $10,000 \mathrm{~g}$ supernatant from the liver homogenate as described (Parkinson and Safe, 1979).

The activity of NADPH-cytochrome $c$ reductase, benzo[a]pyrene (B[a]P) hydroxylase, and dimethylaminoantipyrine (DMAP) $N$-demethylase, the carbon monoxide (CO)- and ethylisocyanide (EIC)-difference spectra, and the concentration of cytochrome $b_{5}$ were determined as described (Parkinson et al., 1980b).

Statistical analysis. Comparing a control with a large number of treatment groups can result in a high probability of apparently large differences appearing by chance alone. This experiment-wise error rate was minimized to a level $\alpha$ by the application of Dunnett's (1964) multiple comparison procedure, with adjustment for unequal sample sizes. Some variables such as $\mathrm{B}[a] \mathrm{P}$ hydroxylase exhibit severe variance heterogeneity. If this is accounted for in the application of Dunnett's procedure the effective degrees of freedom are smaller than is needed for the use of his table. Additionally variance estimates are unstable with small sample size and the adequacy of his table may be in doubt. Therefore Cochran's method (Cochran, 1964; Snedecor and Cochran, 1967) was used for the $\mathrm{B}[a] \mathrm{P}$ hydroxylase data. The nominal $\alpha$ level was divided by 11 , the number of treatment groups, to take the multiple comparisons problem into account. This conservative procedure results in fewer significant differences. For comparison the results of both methods are indicated in Table 3. Some distortion is apparent from the use of a pooled variance estimate in Dunnett's procedure.

\section{RESULTS}

\section{Chemical Analysis}

The chemical composition of fireMaster BP-6 and its various Florisil and alumina fractions is shown in Table 2. Wherever possible, the structure of the individual components was assigned by comparison of retention times with previously identified brominated biphenyls (Moore and Aust, 1978; Moore et al., 1980; Dannan and Aust, personal communication) and with synthetic standards (Robertson et al., 1980a,b). The chemical composition of the most polar Florisil fraction, $\mathrm{F}_{\mathrm{C}}$, is not given in Table 2 . This fraction contained five compounds with retention times of $1.61,2.52,3.21,4.02$, and $5.79 \mathrm{~min}$ comprising approximately 1.9 , $68,4.7,19$, and $4.8 \%$ of $F_{C}$, respectively. The structure of the chemicals in $F_{C}$ could not be assigned on the basis of comparitive retention times with available standards.

Further fractionation of $A_{B}$ by TLC and analysis of the fractions by GC-MS revealed the presence of several penta-, hexa-, and heptabromobiphenyls (see Table 2) as well as monochloro derivatives of pentaand hexabromobiphenyl (i.e., $\mathrm{C}_{12} \mathrm{H}_{4} \mathrm{Br} 5 \mathrm{Cl}$ and $\mathrm{C}_{12} \mathrm{H}_{3} \mathrm{Br}_{6} \mathrm{Cl}$ ) and small amounts of hexabromonaphthalene $\left(\mathrm{C}_{10} \mathrm{H}_{2} \mathrm{Br}_{6}\right)$. No brominated dibenzofurans or dibenzo-p-dioxins were detected in $\mathrm{A}_{\mathrm{B}}$ by GC-MS analysis.

\section{Enzyme Induction}

The effects of fireMaster BP-6 and its Florisil and alumina fractions on the hepatic microsomal drug-metabolizing enzymes were compared to the inductive effects of $\mathrm{PB}, \mathrm{MC}$, or their coadministration $(\mathrm{PB}+\mathrm{MC})$. The results are shown in Table 3.

The hallmarks of PB induction included (1) a proliferation of the endoplasmic re- 
TABLE 2

The Identity, Concentration, and Mode of Induction of the Brominated Biphenyls in FireMASTER AND ITS CHROMATOGRAPHIC FRACTIONS

\begin{tabular}{|c|c|c|c|c|c|c|c|c|}
\hline \multirow{3}{*}{$\begin{array}{l}\text { Retention } \\
\text { time } \\
(\min )\end{array}$} & \multirow[b]{3}{*}{ Structure } & \multirow{3}{*}{$\begin{array}{c}\text { Unfractionated } \\
\text { fireMaster } \\
\text { BP-6 }\end{array}$} & \multicolumn{4}{|c|}{ Percentage of total } & & \\
\hline & & & \multicolumn{2}{|c|}{ Florisil fractions } & \multicolumn{2}{|c|}{ Alumina fractions } & \multicolumn{2}{|c|}{ Type inducer } \\
\hline & & & $\mathrm{F}_{\mathrm{A}}$ & $\mathrm{F}_{\mathrm{B}}$ & $A_{A}$ & $A_{B}$ & PBB & PCB \\
\hline 1.35 & $2,2^{\prime}, 5,5^{\prime}$ & 0.062 & 0.053 & 0.53 & 0.070 & 0.026 & Weak PB $^{a}$ & Not an induce $r^{b, c}$ \\
\hline 1.64 & $?^{d}$ & 0.046 & $\mathrm{NQ}^{e}$ & 0.86 & NQ & NQ & & \\
\hline 2.19 & ? & 0.74 & 0.13 & 0.13 & 0.15 & 0.85 & & \\
\hline 2.82 & $2,2^{\prime} 4,5,5^{\prime}$ & 3.2 & 3.1 & 2.5 & 3.4 & 0.73 & $\mathbf{P B}^{a}$ & \\
\hline 3.68 & $?$ & NQ & NQ & 0.18 & 0.16 & 0.51 & & \\
\hline 4.50 & $2,3^{\prime}, 4,4^{\prime}, 5$ & 3.4 & 3.2 & 3.7 & 3.5 & 2.2 & $\mathbf{P B}+\mathbf{M C}^{f}$ & $\mathrm{~PB}+\mathrm{MC}^{g}$ \\
\hline 5.34 & $2,2^{\prime}, 3^{\prime}, 4,5,6^{\prime}$ & 0.93 & 0.93 & 0.78 & 0.98 & 1.2 & & \\
\hline 6.22 & $2,2^{\prime}, 4,4^{\prime}, 5,5^{\prime}$ & 62 & 59 & 44 & 58 & 8.3 & $\mathrm{~PB}^{a, h, i}$ & $\mathrm{~PB}^{j}$ \\
\hline 8.02 & $2,2^{\prime}, 3,4,4^{\prime}, 5^{\prime}$ & 9.3 & 9.4 & 15 & 9.6 & 13 & & $\mathrm{~PB}+\mathrm{MC}^{k, l}$ \\
\hline 9.46 & $2,3^{\prime}, 4,4^{\prime}, 5,5^{\prime}$ & 4.3 & 4.9 & 6.6 & 5.4 & 2.9 & $\mathbf{P B}+\mathbf{M C}^{m}$ & $\mathrm{~PB}^{o}$ \\
\hline 11.43 & $2,3,3^{\prime}, 4,4^{\prime}, 5$ & 0.33 & 1.9 & 3.5 & 2.2 & 8.2 & & $\mathrm{~PB}+\mathrm{MC}^{\mathrm{g} \cdot n}$ \\
\hline 16.04 & $2,2^{\prime}, 3,4,4^{\prime}, 5,5^{\prime}$ & 15 & 16 & 14 & 16 & 15 & $\mathbf{P B}^{\circ}$ & \\
\hline 21.23 & $2,2^{\prime}, 3,3^{\prime}, 4,4^{\prime}, 5$ & 0.23 & NQ & 4.3 & 0.29 & 28 & & $\mathrm{~PB}^{n}$ \\
\hline 23.12 & $?$ & NQ & NQ & NQ & 0.28 & 2.5 & & \\
\hline 27.03 & $?$ & NQ & NQ & NQ & NQ & 1.4 & & \\
\hline 39.56 & $?$ & NQ & NQ & NQ & NQ & 7.3 & & \\
\hline
\end{tabular}

a Robertson et al. (1980a).

${ }^{b}$ Goldstein et al. (1977).

c Crawford and Safe (1979).

¿ ?, Structure unknown.

NQ. Not quantified.

${ }^{f}$ Robertson et al. (1980b).

${ }^{g}$ Parkinson et al. (1980b).

${ }^{h}$ Moore et al. (1978).

${ }^{i}$ Goldstein et al. (1979).

${ }^{j}$ Goldstein et al. (1978).

${ }^{k}$ Stonard and Greig (1976).

'Alvares (1977).

m Dannen et al. (1978).

${ }^{n}$ Yoshihara et al. (1979).

"Moore et al. (1979).

ticulum (as indicated by an increase in the $\mathrm{mg}$ microsomal protein per $\mathrm{g}$ liver), (2) a general increase in the liver to body weight ratio, (3) a 2.5 - to 3.5 -fold increase in the concentration of cytochrome $P-450$ and the activity of DMAP $N$-demethylase, $\mathrm{B}[a] \mathrm{P}$ hydroxylase, and NADPH-cytochrome $c$ reductase, and (4) a peak at 450.0 $\mathrm{nm}$ in the CO-difference spectrum and two peaks at 428.0 and $455.0 \mathrm{~nm}$ in the EICdifference spectrum with a $455: 425 \mathrm{~nm}$ peak height ratio of about $1: 2$. In general, the hemoproteins induced by PB were qualitatively similar in both enzymic and ligandbinding properties to the constitutive forms of cytochrome $P-450$ in noninduced microsomes. Induction by treatment with $\mathrm{MC}$ was characterized by (1) a small (but statistically significant) increase in microsomal protein content and in liver to body weight ratio, (2) a twofold increase in cytochrome $P-450(P-448)$ content, (3) a 15 -fold increase in $\mathrm{B}[a] \mathrm{P}$ hydroxylase activity but with very little increase in DMAP $N$-demethylase and NADPH-cytochrome $c$ reductase activity, and (4) a peak at $448.0 \mathrm{~nm}$ in the COdifference spectrum and two peaks at 429.7 and $452.0 \mathrm{~nm}$ in the EIC-difference spectrum with a $452.0: 429.7 \mathrm{~nm}$ peak height ratio of about $2: 1$. In contrast to PB, the MC- 


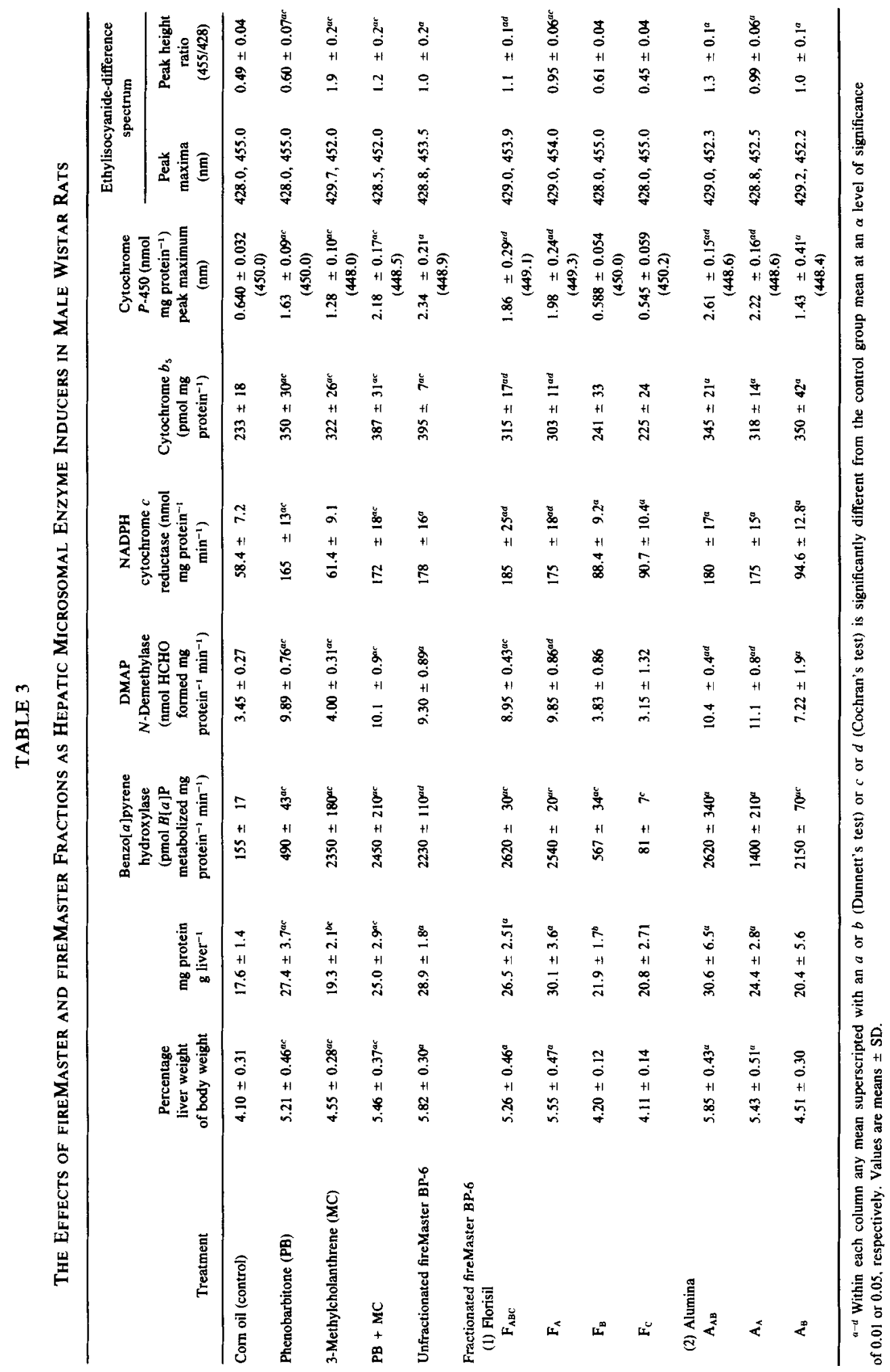


induced hemoproteins displayed qualitatively distinct enzymic and ligand-binding properties compared to noninduced microsomes.

The 15-fold increase in $\mathrm{B}[a] \mathrm{P}$ hydroxylase activity, characteristic of MC induction, and the threefold increase in both DMAP $N$-demethylase and NADPHcytochrome $c$ reductase activity, characteristic of $P B$ induction, were all apparent when $\mathrm{PB}$ and $\mathrm{MC}$ were coadministered. The additive effects of these two inducers was also evident from the magnitude of the increase in cytochrome $P-450$ concentration. A $1.5 \mathrm{~nm}$ hypsochromic shift in the CO-difference spectrum and a $0.5 \mathrm{~nm}$ bathochromic and $3.0 \mathrm{~nm}$ hypsochromic shift in the 428.0 and $455 \mathrm{~nm}$ peaks, respectively, of the EIC-difference spectrum were observed following the coadministration of $\mathrm{PB}$ with MC. These spectral shifts, together with approximately equal peak heights in the EIC-difference spectrum, indicated that the qualitative ligand-binding characteristics displayed by (PB + MC)-induced microsomes were intermediate between PB- and MC-induced microsomes.

The data presented in Table 3 summarize the effects of fireMaster BP-6 and the diverse alumina and Florisil fractions as rat hepatic microsomal enzyme inducers. The least polar alumina $\left(A_{A}\right)$ and Florisil $\left(F_{A}\right)$ fractions were similar in composition to the unfractionated fireMaster BP-6 and exhibited comparable mixed-type induction activities. The more polar Florisil fractions, $F_{B}$ and $F_{C}$, were weak inducers whereas the polar alumina fraction $A_{B}$ was a highly potent inducer of both DMAP $N$-demethylase and $\mathrm{B}[a] \mathrm{P}$ hydroxylase microsomal enzymes.

\section{DISCUSSION}

The purpose of this study was to test whether the ability of fireMaster BP-6 and its various chromatographic fractions to induce the hepatic microsomal drug- metabolizing enzymes could be correlated with the chemical composition of each fraction knowing the inductive effects of many of the individual brominated biphenyls in fireMaster BP-6 (or their chloro analogs).

The results presented in Table 3 show that the more polar fraction(s) eluted from a Florisil column $\left(F_{B}\right.$ and $\left.F_{C}\right)$ or from an alumina column $\left(A_{B}\right)$ differed both qualitatively and quantitatively in their ability to induce the hepatic microsomal drugmetabolizing enzymes in the male rat. The more polar Florisil fractions were relatively ineffective in inducing the drug-metabolizing enzymes. These data confirm the absence of the potentially active bromodibenzofurans and dioxins (Hass et al., 1978) which would elute in the polar Florisil fractions.

In contrast to the polar Florisil fraction, the more polar fraction eluted from alumina, $A_{B}$, causes rabbit car hyperkeratosis (Kimbrough et al., 1977) and was found in the present study to be a potent inducer of both cytochrome $P$-450-dependent and cytochrome $P$-448-dependent monooxygenases. As shown in Table 3 the cytochrome $P$-448-dependent monoxygenase, $\mathrm{B}[a] \mathrm{P}$ hydroxylase, was almost maximally induced by fraction $A_{B}$. The results of the biologic effects of the Florisil and alumina fractions are consistent with, but do not prove, the hypothesis that, like other classes of halogenated aryl hydrocarbons, a correlation may exist between the toxicity of PBBs and their ability to induce cytochrome $P-448$.

The brominated biphenyl congeners which have been identified in fire Master BP-6 are categorized into PB-type and MCtype inducers in Table 2. The more complete data for the corresponding chloro analogs are also shown. From Table 2, it is evident that only two fireMaster components, namely, 2,3',4,4',5-penta- and 2,3',4,4',$5,5^{\prime}$-hexabromobiphenyl, have been shown to induce cytochrome $P$-448. Two chlorinated biphenyls, namely, $2,2^{\prime}, 3,4,4^{\prime}, 5^{\prime}-$ 
hexa- and $2,3,3^{\prime}, 4,4^{\prime}, 5$-hexachlorobiphenyl, have been reported to induce cytochrome $P$-448, but their corresponding brominated biphenyls have yet to be tested. These data suggest that, of those components identified, a total of four brominated biphenyls (namely, 2,3',4,4',5-penta-, $2,3^{\prime}, 4,4^{\prime}, 5,5^{\prime}$-hexa-, $2,2^{\prime}, 3,4,4^{\prime}, 5^{\prime}$-hexa-, and $2,3,3^{\prime}, 4,4^{\prime}, 5$-hexabromobiphenyl) are potential contributors to the MC-type character of fireMaster BP-6. It should be noted that each of these congeners would be expected to induce cytochrome $P-450$ as well as cytochrome $P$-448.

Although the percentage of $2,3^{\prime}, 4,4^{\prime}, 5$ penta-, $2,3^{\prime}, 4,4^{\prime}, 5,5^{\prime}$-hexa-, and $2,2^{\prime}, 3,4,4^{\prime},-$ $5^{\prime}$-hexabromobiphenyl was slightly higher in $F_{B}$ than $A_{B}$, the amount of $A_{B}$ injected was 10 times that of $F_{B}$. Consequently, rats treated with $A_{B}$ received a greater amount of all four congeners expected to induce cytochrome $P$-448 than rats treated with $F_{B}$. These data suggest that the differential effects of $A_{B}$ and $F_{B}$ on the hepatic microsomal drug-metabolizing enzymes can be correlated in part with differences in their chemical composition. However, it should be noted that based on the distribution $2,3^{\prime}, 4,4^{\prime}, 5$-penta-, $2,3^{\prime}, 4,4^{\prime}, 5,5^{\prime}$-hexa-, $2,3,3^{\prime}, 4,4^{\prime}, 5$-hexa-, and $2,2^{\prime}, 3,4,4^{\prime}, 5^{\prime}$-hexabromobiphenyl in $A_{A}$ and $A_{B}$, the former, rather than the latter, would be expected to be the more potent inducer of cytochrome $P$-448. This suggests that components as yet unidentified may contribute to the MCtype character of fireMaster BP-6 and that potentially toxic fireMaster BP-6 components have yet to be identified. It is also possible that due to synergistic effects the biologic activity of the commercial PBB mixture may not be the sum of the activities of its components. Research is in progress to synthesize and test the congeneric PBBs and reconstituted mixtures.

\section{ACKNOWLEDGMENTS}

The authors wish to thank Mr. H. S. McKinnon for his help in obtaining the GC-MS data, Dr. John Holt,
Department of Mathematics and Statistics, University of Guelph, for his help in the statistical analyses of the data in Table 3, and the Research Programs Directorate, Health and Welfare Canada (606-1444X), the National Cancer Institute (5 R01CA21814-02), the Natural Sciences and Engineering Research Council of Canada, and the Environmental Protection Agency (CR 806928010) for financial assistance.

\section{REFERENCES}

Alvares, A. P. (1977). Stimulatory effects of polychlorinated biphenyls (PCB) on cytochromes P-450 and P-448 mediated microsomal oxidations. In Microsomes and Drug Oxidations (V. Ullich, ed.), pp. 476-483. Pergamon Press, New York.

Ax, R. L., AND HANSEN, L. G. (1975). Effects of purified PCB analogs on chicken reproduction. Poultry Sci. 54, 895-900.

Bowes, G. W., Mulvihill, M. J., Simoneit, B. R. T., Burlingame, A. L., and Risebrough, R. W. (1975). Identification of chlorinated dibenzofurans in American polychlorinated biphenyls. Nature (London) 256, 305-307.

Cochran, W. G. (1964). Approximate significance levels of the Behrens-Fisher test. Biometrics 20, 191-195.

Crawford, A., and SAFE, S. (1979). 4-Chlorobiphenyl metabolism: The effects of chemical inducers. Gen. Pharmacol. 10, 227-231.

Dannan, G. A., Moore, R. W., Besaw, L. C., AND AUST, S. D. (1978), $2,4,5,3^{\prime}, 4^{\prime}, 5^{\prime}$-Hexabromobiphenyl is both a 3-methylcholanthrene- and a phenobarbital-type inducer of microsomal drug metabolizing enzymes. Biochem. Biophys. Res. Commun. 85, 450-458.

DunNeTt, G. W. (1964). New tables for multiple comparisons with a control. Biometrics 20, 482-491.

GolDSTEIN, J. A. (1979). The structure-activity relationships of halogenated biphenyls as enzyme inducers. Ann. N.Y. Acad. Sci. 320, 164-178.

Goldstein, J. A., Hass, J. R., Linko, P., and HarVAN, D. J. (1978). 2,3,7,8-Tetrachlorodibenzofuran in a commercially available $99 \%$ pure polychlorinated biphenyl isomer identified as the inducer of hepatic cytochrome P-448 and aryl hydrocarbon hydroxylase in the rat. Drug Metab. Dispos. 6, 258-264.

Goldstein, J. A., Hickman, P., Bergman, H. MCKINNEY, J. D., AND WALKER, M. P. (1977). Separation of pure polychlorinated biphenyl isomers into two types of inducers on the basis of induction of cytochrome P-450 or P-448. Chem. Biol. Interact. 17, 69-87.

Goldstein, J. A., Linko, P. C., Levy, L. A., 
MCKinney, J. D., GuPta, B. N., AND Moore, J. A. (1979). A comparison of a commercial polybrominated biphenyl mixture, $2,4,5,2^{\prime}, 4^{\prime}, 5^{\prime}$-hexabromobiphenyl and 2,3,6,7-tetrabromonaphthalene as inducers of liver microsomal drug-metabolizing enzymes. Biochem. Pharmacol. 28, 2947-2956.

Hass, J. R., McConnell, E. E., AND HaRvan, D. J. (1978). Chemical and toxicologic evaluation of Firemaster BP-6. J. Agric. Food. Chem. 26, 94-99.

Kimbrough, R. D., Burse, V. W., Liddle, J. A., AND FrIES, G. F. (1977). Toxicity of polybrominated biphenyl. Lancet (September 17, 1977), 602-603.

McKinney, J. D., Chae, K., Gupta, B. N., Moore, J. A., ANd Goldstein, J. A. (1976). Toxicological assessment of hexachlorobiphenyl isomers and 2,3,7,8-tetrachlorodibenzofuran in chicks. Toxicol. Appl. Pharmacol. 36, 65-80.

Moore, R. W., And Aust, S. D. (1978). Purification and structural characterization of polybrominated biphenyl congeners. Biochem. Biophys. Res. Commun. 84, 936-942.

Moore, R. W., Dannan, G. A., And Aust, S. D. (1980). Structure-function relationships for the pharmacological and toxicological effects and metabolism of polybrominated biphenyl congeners. In Molecular Basis of Environmental Toxicity (R. S. Bhatnagar, ed.), Chapter 8. Ann Arbor Science Publishers, Ann Arbor, Michigan.

Moore, R. W., Sleight, S. D., and Aust, S. D. (1978). Induction of liver microsomal drugmetabolizing enzymes by $2,2^{\prime}, 4,4^{\prime}, 5,5^{\prime}$-hexabromobiphenyl. Toxicol. Appl. Pharmacol. 44, 309-321.

Moore, R. W., Sleight, S. D., and Aust, S. D. (1979). Effects of 2,2'-dibromobiphenyl and $2,2^{\prime}, 3,4,4^{\prime}, 5,5^{\prime}$-heptabromobiphenyl on liver microsomal drug metabolizing enzymes. Toxicol. Appl. Pharmacol. 48, 73-86.

Parkinson, A., Cockerline, R., and Safe, $S$. (1980b). Polychlorinated biphenyl isomers and congeners as inducers of both 3-methylcholanthrene- and phenobarbitone-type microsomal enzyme activity. Chem. Biol. Interact. 29, 277-289.

Parkinson, A., Robertson, L., Safe, L., AND Safe, S. (1980a). Polychlorinated biphenyls as inducers of hepatic microsomal enzymes: Structure-activity rules. Chem. Biol. Interact. 30, 271-285.

Parkinson, A., and Safe, S. (1979). The detection of enzyme induction by rat liver microsomes prepared by isoelectric precipitation. J. Pharm. Pharmacol. 31, 444-447.

Poland, A., Greenlee, W. F., and Kende, A. S. (1979). Studies on the mechanism of action of the chlorinated dibenzo-p-dioxins and related compounds. Ann. N.Y. Acad. Sci. 320, 214-230.

Poland, A., and Giover, F. (1977). Chlorinated biphenyl induction of aryl hydrocarbon hydroxylase activity: A study of the structure-activity relationship. Mol. Pharmacol. 13, 924-938.

PorTer, M. L., AND Burke, J. A. (1971). Separation of three chlorodibenzo-p-dioxins from some polychlorinated biphenyls by chromatography on an aluminum oxide column. J. Assoc. Off. Anal. Chem. 54, 1426-1428.

Roach, J. A. G., And Pomerantz, I. H. (1974). The finding of chlorinated dibenzofurans in a Japanese polychlorinated biphenyl sample. Bull. Environ. Contam. Toxicol. 12, 338-342.

Robertson, L. W., Parkinson, A., and Safe, S. (1980a). Paper presented at the nineteenth annual meeting, Society of Toxicology, Washington, D.C., March 9-13.

Robertson, L. W., Parkinson, A.. and Safe, S. (1980b). Induction of both cytochromes P-450 and $\mathrm{P}-448$ by $2,3^{\prime}, 4,4^{\prime}, 5$-pentabromobiphenyl, a component of fireMaster. Biochem. Biophys. Res. Commun. 92, 175-182.

Snedecor, G. W., and Cochran, W. G. (1967). Statistical Methods, 6th ed., p. 114. Iowa State University Press.

Stonard, M. D., And Greig, J. B. (1976). Different patterns of hepatic microsomal enzyme activity produced by administration of pure hexachlorobiphenyl isomers and hexachlorobenzene. Chem. Biol. Interact. 15, 365-379.

Vos, J. G., Koeman, J. H., Van Der Maas. H. L., Ten Noever de Brauw, M. C., and de Vos, R. H. (1970). Identification and toxicological evaluation of chlorinated dibenzofuran and chlorinated naphthalene in two commercial polychlorinated biphenyls. Food Cosmet. Toricol. 8, 625-633.

Yamamoto, H., Yoshimura, H., Fujita, M., and Yamamoio, T. (1976). Metabolic and toxicologic evaluation of $2,3,4,3^{\prime}, 4^{\prime}$-pentachlorobiphenyl in rats and mice. Chem. Pharm. Bull. 24, 2168-2174.

Yoshihara, S., Kawano, K., Yoshimura, H., KURoKi, H., AND MAsuda, Y. (1979). Toxicological assessment of highly chlorinated biphenyl congeners retained in the yusho patients. Chemosphere 8, 531-538.

Yoshimura, H., Yoshihara, S., Ozawa, N., and MiKI, M. (1979). Possible correlation between induction modes of hepatic enzymes by PCBs and their toxicity in rats. Ann. N.Y. Acad. $S_{c i}, 320$, 179-192. 